\title{
Analisis Pendapat Imam Madzhab Arba'ah dalam Penentuan Batas Akhir Salat Isya dan Implikasinya terhadap Penetapan Jadwal Waktu Salat di Kota Bandung
}

\author{
Agus Firmansyah*, Fahmi Fatwa Rosyadi \\ Prodi Hukum Keluarga Islam, Fakultas Syariah, Universitas Islam \\ Bandung, Indonesia. \\ *agusfrmnsyah17@gmail.com, fahmifatwarosyadi@unisba.ac.id

\begin{abstract}
The fourth sect as a the bigger segt in islam and approved in Indonesia. Is islam thought the fourth sect has different each other and in this research is about the differentiation of the deadline of isha prayer. There is three opinions. First is until before morning prayer, second until middle nighrt and the last is until one-third of the night. Kemenag does not decided the deadline of prater, and only provide the criteria og the beginning of prayer. Rhe method used to in determine the beginning of isha prayer not only quran and hadist however astronomy or hisab method. This research use qualitative research method and descriptive analysis and literature review. And the result of this research is the priest of fourth sech has a different judgement to decide the deadline for prayer. And Kemenag only explain the criteria the beginning of prayer.
\end{abstract}

Keywords: Forth Sect, Isha Prayer, and Kemenag.

Abstrak. Madzhab arba'ah kita kenal sebagai madzhab 4 imam yang terbesar dan diakui di Indonesia, dalam khazanah fiqih Imam arba'ah terdapat perbedaan, dan perbedaan yang diangkat di sini adalah tentang batas akhir waktu salat isya, ada yang berpendapat sampai akhir, sampai pertengahan dan sepertiga malam. Kemenag tidak menentukan batasan akhir waktu salat isya, namun hanya memberikan kriteria awal waktu salat isya, metode yang digunakan dalam penentuan awal waktu salat isya kemenag bukan hanya merujuk pada Al-Qur'an dan hadits namun menggunakan metode astronomis atau kita kenal hisab. Metode yang digunakan dalam penelitian ini adalah metode penelitian kualitatif yang bersifat deskriptif analisis, teknik data yang dikumpulkan melalui studi kepustakaan. Hasil dari penelitian ini adalah para ulama madzhab arba'ah berbeda pendapat dalam menentukan batas akhir waktu salat karena melihat dari beberapa hadits yang mereka rujuk, dan kemenag hanya menjelaskan awal waktu salat saja menurut kriteria yang kemenag jelaskan.

Kata Kunci: Madzhab Arba'ah, Salat Isya, Kemenag. 


\section{A. Pendahuluan}

Shalat merupakan persoalan yang sangat signifikan dalam Islam. Sehingga, Islam memposisikan shalat sebagai suatu yang khusus dan fundamental, yaitu shalat sebagai salah satu rukun Islam yang harus ditegakkan. Secara syar'i, dalam menunaikan kelima waktu shalat tersebut, kaum muslimin terikat pada waktu-waktu yang sudah ditentukan sesuai dengan permahaman ayat-ayat Al-quran maupun Hadits tentang waktu shalat.

Dan mengingat betapa pentingnya mengetahui waktu-waktu salat ini, para ulama sepanjang sejarah peradaban Islam telah mencurahkan perhatiannya terhadap persoalan ini. Bila kita simak, hampir semua literatur-literatur fikih klasik dalam berbagai madzhab memuat bahasan mengenai waktu-waktu salat.

Pendapat Imam madzhab terdapat perbedaan pendapat dalam penentuan batas akhir waktu salat isya, itu ada tiga pendapat yaitu sampai pertengahan malam, pertigaan malam, dan sampai menjelang waktu subuh, kita dapat memilih dari ketiga pendapat tersebut yang paling diyakini.

Imam Hanafi berpendapat bahwa waktu salat isya sampai dengan akhir waktu fajar, imam malik menyatakan bahwa akhir waktu salat isya itu sampai dengan pertengahan malam, imam syafi'I berpendapat dalam pendapat barunya yaitu qaul jadid sampai sepertiga malam, dan terakhir imam hanbali berpendapat sampai dengan akhir waktu fajar. Dengan perbedaan itulah perlunya untuk diteliti dan bagaimana implikasinya dalam penetapan waktu salat di kemenag kota Bandung.

Berdasarkan latar belakang yang telah diuraikan di atas, maka tujuan dari penelitian ini adalah sebagai berikut:

1. Bagaimana pendapat Imam madzhab terhadap batas akhir waktu solat isya?

2. Bagaimana implikasinya terhadap penetapan jadwal waktu solat di kota bandung?

\section{B. Metodologi Penelitian}

Metode yang digunakan dalam penelitian ini adalah metode penelitian kualitatif yang bersifat deskriptif analisis, teknik data yang dikumpulkan melalui studi kepustakaan.

Shalat merupakan persoalan yang sangat signifikan dalam Islam. Sehingga, Islam memposisikan shalat sebagai suatu yang khusus dan fundamental, yaitu shalat sebagai salah satu rukun Islam yang harus ditegakkan. Secara syar'i, dalam menunaikan kelima waktu shalat tersebut, kaum muslimin terikat pada waktu-waktu yang sudah ditentukan sesuai dengan permahaman ayat-ayat Al-Quran maupun Hadits tentang waktu shalat. Hal ini sebagaimana yang telah diisyaratkan dalam surat An-Nisa : 103.

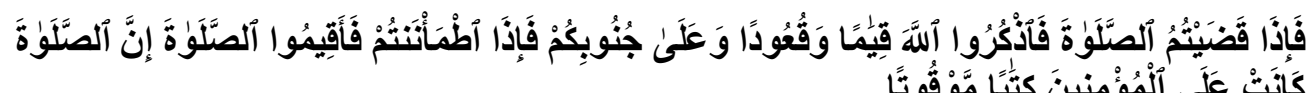

Artinya:

"Maka apabila kamu telah menyelesaikan shalat(mu), ingatlah Allah di waktu berdiri, di waktu duduk dan di waktu berbaring. Kemudian apabila kamu telah merasa aman, maka dirikanlah shalat itu (sebagaimana biasa). Sesungguhnya shalat itu adalah fardhu yang ditentukan waktunya atas orang-orang yang beriman.” ( QS. An-Nisa : 103)

Konsekuensi logis dari ayat tersebut adalah shalat tidak bisa dilakukan dalam sembarangan waktu, melainkan harus mengikuti atau berdasarkan dalil-dalil baik dari AlQuran maupun Hadits. Adanya ketentuan waktu yang telah termuat didalamnya melahirkan pemahaman bahwa ketentuan waktu-waktu shalat tersebut berkaitan dengan posisi matahari pada bola langit. Data astronomis terpenting dalam penentuan awal waktu shalat adalah posisi matahari terutama tinggi matahari, seperti fenomena awal fajar (morning twilight), matahari terbit (sunrise), matahari melintasi meridian (culmination), matahari terbenanm (sunset).

Seperti diisyaratkan QS. An-Nisa' ayat 103, salat dalam pelaksanaanya limit akhir. Sejatinya istilah awal dan akhir waktu shalat secara secara definitif tidak ditemukan baik di dalam Al-Quran maupun as-sunnah, keduanya hanya memberi isyarat bahwa waktu-waktu salat itu memiliki waktu.

Hadits Nabi saw yang diriwayatkan oleh Imam Muslim dari Abdullah bin Amr ra. 


$$
\begin{aligned}
& \text { عن عبدالله بن عمر رضى الله عنه قال ان النبى صلعم قال وقت الظهز اذا زالت الشمس وكا ن ظل كل الرجل المقل كطوله مالم يكضر العصر }
\end{aligned}
$$

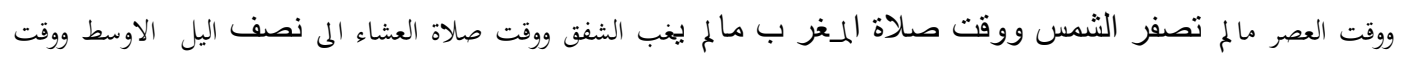

$$
\begin{aligned}
& \text { صلاةالصبح من طلوع الفجر مالم تطلع الشمس(روه مسلم) }
\end{aligned}
$$

Artinya: "Dari Abdullah bin Amar r.a berkata: Sabda Rasulullah SAW; waktu dhuhur apabila tergelincir matahari, sampai bayang-bayang seseorang sama dengan tingginya, yaitu selama belum datang waktu ashar. Dan waktu ashar selama matahari belum menguning. Dan waktu maghrib selama syafaq belum terbenam(mega merah). Dan sampai tengah malam yang pertengahan. Dan waktu shubuh mulai fajar menyingsing sampai selama matahari belum terbit." (HR. Muslim).

Istilah awal dan akhir waktu salat yang sudah demikian popular dikalangan masyarakat muslim sesungguhnya lahir dari ijtihad para ulama dalam menerjemahkan ayatayat dan hadits-hadits berkaitan dengan waktu salat. Seperti diisyaratkan, waktu-waktu salat ditentukan berdasarkan fenomena matahari. Oleh karena matahari dalam peredarannya di cakrawala bersifat tetap dan eksak sepanjang tahun, umat Islam generasi awal hingga era modern memiliki rumusan yang berbeda-beda dalam mendefinisikan awal dan akhir waktuwaktu salat sebagai pemahaman dan penerjemahan mereka terhadap teks-teks terkait.

\section{Hasil Penelitian dan Pembahasan}

Berdasarkan penelitian pendapat Imam Madzhab terdapat perbedaan pendapat dalam penentuan batas akhir waktu salat isya, itu ada tiga pendapat yaitu sampai pertengahan malam, pertigaan malam, dan sampai menjelang waktu subuh, kita dapat memilih dari ketiga pendapat tersebut yang paling di yakini.

Imam Hanafi berpendapat bahwa waktu salat isya sampai dengan akhir waktu fajar, pendapat tersebut berdasarkan hadits

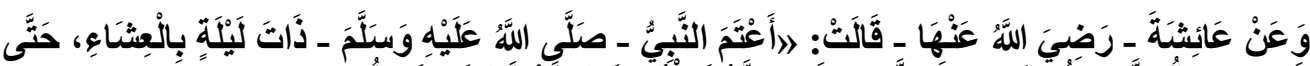

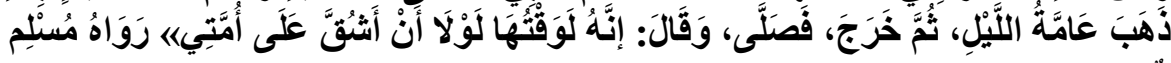

Dari Aisyah RA bahwasanya suatu malam Rasulullah SAW mengakhirkan shalat Isya, hingga sebagian malam telah berlalu, kemudian beliau keluar seraya menunaikannya, lalu bersabda, "Sungguh saat inilah waktunya, seandainya tidak memberatkan umatku."(HR. Muslim).

Sedangkan imam malik menyatakan bahwa akhir waktu salat isya itu sampai dengan pertengahan malam, dapat dilihat pada hadits 'Abdullah bin 'Amr.

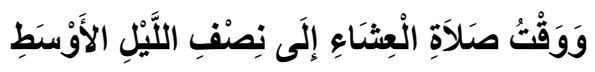

“Waktu shalat Isya' adalah hingga pertengahan malam.” (HR. Muslim no. 612).

Imam syafi'I berpendapat dalam pendapat barunya yaitu qaul jadid sampai sepertiga malam. Hal ini didasarkan pada hadits dari Abu Bakar ibn Abi Musa dan bapaknya. Yang artinya kemudian ia mengakhirkan shalat Maghrib hingga mega terbenam dan kemudian ia mengakhirkan shalat Isya' hingga sepertiga malam.

Waktu akhir shalat Isya' adalah sepertiga malam, ini waktu ikhtiyari (waktu pilihan). Sedangkan waktu akhir shalat Isya' yang bersifat darurat adalah hingga terbit fajar. Waktu darurat ini misalnya ketika seseorang sakit lantas sembuh ketika waktu darurat, maka ia masih boleh mengerjakan shalat Isya' di waktu itu. Begitu pula halnya wanita haid, wanita nifas ketika mereka suci di waktu tersebut. Inilah pendapat ulama Hanabilah.

Dalam penetapan waktu salat kemenag tidak terikat pada satu madzhab tertentu melainkan pada tinjauan astronomis. Namun apabila dilihat dari kriteria yang dilakukan oleh kemenag, kemenag tidak menentukan batasan akhir waktu salat isya dengan demikian kemenag hanya menentukan awal waktu salat saja. 


\section{Kesimpulan}

Berdasarkan hasil penelitian yang dilakukan, maka dapat diambil beberapa kesimpulan sebagai berikut:

1. Dalam penetapan batas akhir waktu salat Isya para ulama madzhab arba'ah seperti Imam Hanafi bahwa waktu salat isya sampai dengan akhir waktu fajar, Imam Malik menyatakan bahwa akhir waktu salat isya itu sampai dengan pertengahan malam, Imam Syafi'I berpendapat dalam pendapat barunya yaitu qaul jadid sampai sepertiga malam, dan terakhir Imam Hanbali berpendapat sampai dengan akhir waktu fajar.

2. Dalam penetapan waktu salat kemenag tidak terikat pada satu madzhab tertentu melainkan pada tinjauan astronomis. Namun apabila dilihat dari kriteria yang dilakukan oleh kemenag, kemenag tidak menentukan batasan akhir waktu salat isya dengan demikian kemenag hanya menentukan awal waktu salat saja.

\section{Daftar Pustaka}

[1] Susiknan Azhari, Ilmu Falak; perjumpaan Khazanah Islam dan Sains modern, Yogyakarta: Suara Muhammadiyah, 2007, hlm, 63.

[2] RI, departemen agama, Alquran dan terjemahnya, bandung: syamil cipta, 2015

[3] Susiknan Azhari, Ilmu Falak; perjumpaan Khazanah Islam dan Sains modern, Yogyakarta: Suara Muhammadiyah, 2007, hlm, 66.

[4] Imam An-Nawawi, Syarah Shahih Muslim, Darus Sunnah

[5] Al Mawsu'ah Al Fiqhiyah, Asy Syamilah, 2/2561, index "awqotush sholah", point 13.

[6] Ibnu rusyd, terjemah bidayatul, mujtahid, semarang: cv asy-syifa, 1990, hal 195. 